\title{
PHARMACOKINETICS OF RIFAMPICIN DURING ANTIRETROVIRAL TREATMENT WITH NON-NUCLEOSIDE REVERSE TRANSCRIPTASE INHIBITORS
}

\author{
Hemanth Kumar A. K., Ramachandran G, Rajasekaran S. ${ }^{1}$, Padmapriyadarsini C, Narendran \\ G., Menon P, Narayanan P. R., Swaminathan S.
}

Tuberculosis Research Centre (ICMR), Chetput, Chennai

${ }^{1}$ Government Hospital of Thoracic Medicine, Tambaram, Chennai

\begin{abstract}
Introduction: Co-management of tuberculosis (TB) and HIV is complicated by pharmacologic drug interactions between rifampicin (RMP) and certain classes of antiretroviral agents. The NNRTIs Nevirapine (NVP) or Efavirenz (EFV), used to HIV infection, are known to induce the CYP 450 enzyme system. Thus when RMP is co-administered along with NVP or EFV, the bioavailability of RMP could be lowered leading to drug resistance and treatment failure.

Objectives: To study the steady state pharmacokinetics of RMP in HIV and HIV-TB patients receiving antiretroviral regimens containing NVP or EFV respectively.

Methods: The study population comprised of HIV and HIV-TB patients undergoing antiretroviral treatment with NVP and EFV containing regimens respectively. These patients were also receiving concomitant RMP. Rifampicin was estimated by HPLC in blood collected at different time points after drug administration. The pharmacokinetic variables of RMP were calculated using WinNonlin software.
\end{abstract}

Results \& Conclusions: Co-administration of NVP or EFV did not alter the pharmacokinetics of RMP in HIV and HIV-TB patients, suggesting that the dose of RMP need not be altered during antiretroviral treatment with NVP or EFV.

Key words: Rifampicin; nevirapine; efavirenz; drug-drug interactions; HIV-TB

\section{Correspondence to:}

Dr. Soumya Swaminathan

Deputy Director (Sr.Gr.)

Department of Clinical Research

Tuberculosis Research Centre

Mayor V.R. Ramanathan Road

Chetput, Chennai-600 031

India

Phone: 91-44-28369586

Fax : 91-44-28362528

E-mail: soumyas@trcchennai.in 
doctorsoumya@yahoo.com

\section{Introduction}

Tuberculosis (TB) is of particular concern in HIV-infected patients, and is the most common opportunistic infection observed in HIV-infected individuals. HIV-TB co-infected patients merit special considerations because co-management of both diseases is complicated by potential pharmacologic drug interactions between the rifamycins and nonnucleoside reverse transcriptase inhibitors (NNRTIS). 1, 2

Rifampicin (RMP) is an important first line anti-TB drug and is usually administered for 6-8 months along with other drugs for treatment of TB. This drug is reported to undergo metabolism through the hepatic microsomal cytochrome P-450 (CYP 450) enzyme system. ${ }^{3}$

The standard therapy of HIV infection consists of 2 NRTIs and 1 NNRTI. The NNRTI could be Nevirapine (NVP) or Efavirenz (EFV). Both these drugs are known to induce the CYP 450 enzyme system. 4,5 Thus when RMP is coadministered along with NVP or EFV, the bioavailability of RMP could be lowered leading to drug resistance and treatment failure. The best regimens and appropriate schedule for the administration of both treatments is still not clear.

Lopez et al observed that the pharmacokinetics of RMP did not change substantially in presence of EFV, even when it is administered at elevated doses. ${ }^{6}$ Ribera et al reported that serum RMP levels in patients receiving this drug in combination with NVP were similar to levels found in patients without NVP.7 Their results were consistent with that of Robinson et al. 8 Similar information, to the best of our knowledge, is lacking in HIV and HIV-TB patients in India, who are racially/ethnically different. We report the effect of NVP on RMP pharmacokinetics in HIV-infected patients and that of EFV in HIV-TB patients.

\section{Methods}

Patients: HIV and HIV-TB patients attending the outpatient clinic of the Government Hospital of Thoracic Medicine, Chennai, India, took part in the study. They were required to meet the following inclusion criteria: (i) aged 18 - 50 years, (ii) body weight not less than $30 \mathrm{~kg}$, (iii) no severe hepatic or renal dysfunction (iv) non diabetic, (v) willingness to participate in the study and give informed written consent. These studies were undertaken after obtaining clearance from the Institutional Ethics Committee. Informed written consent was obtained from all the patients.

HIV-infected patients were undergoing treatment with the fixed-dose combination containing NVP (200 mg), lamivudine (150mg), and stavudine (30/40 mg). HIV-TB patients were receiving ART regularly with EFV (600 mg) along with lamivudine (150 mg ) and stavudine (30/40 mg ) / zidovudine 300 mg ) bi-daily. All patients were on ART for atleast two weeks prior to the study. Their anti-TB treatment consisted of RMP (450/600 $\mathrm{mg}$ ), Isoniazid (600 mg), Pyrazinamide (1500 $\mathrm{mg})$ and Ethambutol (1200 mg) thrice weekly for the first 2 months followed by RMP and INH thrice weekly according to Revised National Tuberculosis Control Program regimen (RNTCP).

\section{Conduct of the Study}

NVP-RMP study: Eligible patients were instructed to take RMP once daily (450 mg 
for patients weighing less than $60 \mathrm{~kg}$ and 600 $\mathrm{mg}$ for those weighing more than $60 \mathrm{~kg}$ ) for a period of 6 days along with their antiretroviral regimens, and they were instructed to report to the hospital on day 6 for admission into the ward. The pharmacokinetic study was conducted on day 7 . On the study day, blood samples were drawn in heparinised containers predosing and at 1,2,4,6,8 and 12 hours after administration of antiretroviral drugs and RMP, under supervision.

EFV-RMP study: This study was conducted after admitting the patients to the hospital. A sample of blood was collected on the study day and the EFV and RMP were administered under supervision. Blood samples were collected at different time points after dosing, similar to the NVP-RMP study.

The blood samples were centrifuged and plasma stored at $-20^{\circ} \mathrm{C}$ until assay.

\section{Estimation of Plasma RMP}

Plasma RMP concentrations were estimated by high performance liquid chromatography (Shimadzu Corpn., Kyoto, Japan) according to a validated method. ${ }^{9}$ The intra- and interassay variations observed in the plasma rifampicin estimations were less than $3.5 \%$ and $6.4 \%$ respectively.

\section{Pharmacokinetic analysis}

Based on the plasma concentrations of RMP at different time points, maximum concentration $\left(\mathrm{C}_{\max }\right)$, and time to attain $\mathrm{C}_{\max }$ ( $\left.T_{\max }\right)$ were determined by visual inspection of data. Other pharmacokinetic parameters like $t \frac{1}{2}, \quad A \cup C_{0-12}$ and Clearance were calculated by a non-compartmental model using WinNonlin Software, version 5.1 (Pharsight Corporation., Mountain View, CA).
The pharmacokinetic variables obtained for NVP and EFV groups were compared with that of the historical controls ${ }^{10}$ by independent t-test (SPSS version 13).

\section{Results and Discussion}

The demographic details of all the patients who took part in the study are given in table 1. The steady state pharmacokinetic parameters of RMP when co-administered with NVP or EFV are given in table 2. Data reported from one of our earlier studies on the pharmacokinetics of RMP when administered alone in HIV uninfected TB patients is also given in this table for comparison. ${ }^{10}$ The pharmacokinetic parameters of RMP of patients receiving this drug in combination with NVP or EFV were similar to that found in HIV uninfected patients. A test of significance between the present study data and that obtained from a recently concluded study ${ }^{10}$ showed that none of the pharmacokinetic variables was significantly different between the TB patients and that of NVP and EFV groups

Our results are consistent with earlier reports in which co-administration of RMP along with NVP or EFV did not affect RMP plasma levels. ${ }^{6-8} \quad$ This suggests that the pharmacokinetics of RMP remains unaltered when given along with NVP or EFV despite induction of CYP 3A4 by these antiretroviral drugs, and that the dose of RMP need not be altered during ART. Thus anti-TB treatment containing RMP in standard dosages can be safely used in combination with $A R V$ regimen containing NVP or EFV. The present guidelines recommend the use of EFV when the patient is receiving RMP-containing antiTB treatment. Ongoing studies are evaluating the safety and efficacy of NVP when used along with anti-TB treatment. 
Table 1 Demographic detail of patients

\begin{tabular}{|c|c|c|c|}
\hline Characteristics & & $\begin{array}{l}\mathrm{HIV} \\
\mathrm{n}=13\end{array}$ & $\begin{array}{c}\text { HIV-TB } \\
n=9\end{array}$ \\
\hline Sex (No.) & $\begin{array}{l}\text { Male } \\
\text { Females }\end{array}$ & $\begin{array}{l}9 \\
4\end{array}$ & $\begin{array}{l}7 \\
2\end{array}$ \\
\hline Age (Year) & $\begin{array}{l}\text { Mean } \\
\text { Range }\end{array}$ & $\begin{array}{c}34 \\
28-48\end{array}$ & $\begin{array}{c}34 \\
27-42\end{array}$ \\
\hline $\begin{array}{l}\text { Body weight } \\
(\mathrm{kg})\end{array}$ & $\begin{array}{l}\text { Mean } \\
\text { Range }\end{array}$ & $\begin{array}{c}58 \\
38-91\end{array}$ & $\begin{array}{c}47 \\
34-61\end{array}$ \\
\hline Height (cm) & $\begin{array}{l}\text { Mean } \\
\text { Range }\end{array}$ & $\begin{array}{c}161 \\
145-173\end{array}$ & $\begin{array}{c}160 \\
150-167\end{array}$ \\
\hline $\begin{array}{l}\text { Body Mass } \\
\text { Index (BMI) }\end{array}$ & $\begin{array}{l}\text { Mean } \\
\text { Range }\end{array}$ & $\begin{array}{c}22.2 \\
17.8- \\
33.0\end{array}$ & $\begin{array}{c}18.6 \\
14.3- \\
22.4\end{array}$ \\
\hline $\begin{array}{l}\text { Duration of } \\
\text { ATT (Months) }\end{array}$ & $\begin{array}{l}\text { Mean } \\
\text { Range }\end{array}$ & - & $\begin{array}{c}3.8 \\
0.3-6.0\end{array}$ \\
\hline $\begin{array}{c}\text { Duration of } \\
\text { ART (Months) }\end{array}$ & $\begin{array}{l}\text { Mean } \\
\text { Range }\end{array}$ & $\begin{array}{l}4.5 \\
1-8\end{array}$ & $\begin{array}{c}3.9 \\
0.3-14.0\end{array}$ \\
\hline $\begin{array}{l}\text { CD4 counts } \\
\text { (cells } / \mathrm{mm} 3 \text { ) }\end{array}$ & $\begin{array}{l}\text { Mean } \\
\text { Range }\end{array}$ & $\begin{array}{c}315 \\
60-684\end{array}$ & $\begin{array}{c}114 \\
70-199\end{array}$ \\
\hline
\end{tabular}

Table 2 Steady State Pharmacokinetics of Rifampicin (450/600 mg)

\begin{tabular}{|c|c|c|c|c|c|}
\hline \multicolumn{7}{|c|}{ Mean (range) } \\
\hline & $\begin{array}{c}\mathrm{C}_{\max } \\
(\mu \mathrm{g} / \mathrm{ml}\end{array}$ & $\begin{array}{c}\mathrm{T}_{\max } \\
(\text { hours } \\
)\end{array}$ & $\begin{array}{c}\mathrm{T} 1 / 2 \\
(\text { hours } \\
)\end{array}$ & $\begin{array}{c}\mathrm{AUC}_{(0-} \\
12) \\
(\mu \mathrm{g} / \mathrm{ml} \\
-\mathrm{hrs})\end{array}$ & $\begin{array}{c}\mathrm{Cl} \\
(\text { litres/ } \\
\mathrm{min})\end{array}$ \\
\hline $\begin{array}{c}\text { RMP10 } \\
(\mathrm{n}=\end{array}$ & 7.2 & 2.4 & 3.0 & $33.0^{*}$ & 15.0 \\
13) & $(5.5-$ & $(1.7-$ & $(2.1-$ & $(26.7-$ & $(11.8-$ \\
\hline With & 8.7 & $3.1)$ & $3.9)$ & $39.4)$ & $18.2)$ \\
NVP & $(5.6-$ & $(2.0-$ & 2.1 & 43.7 & 12.4 \\
$(\mathrm{n}=13)$ & $13.5)$ & $4.0)$ & $3.0)$ & $(28.0-$ & $(8.6-$ \\
\hline With & 7.7 & 2.3 & 2.3 & 37.8 & 12.9 \\
EFV & $(4.8-$ & $(1.0-$ & $(1.9-$ & $(15.0-$ & $(8.0-$ \\
$(\mathrm{n}=9)$ & $11.1)$ & $4.0)$ & $5.1)$ & $53.2)$ & $29.1)$ \\
\hline
\end{tabular}

* denotes AUC 0 to 8 ( $\mu \mathrm{g} / \mathrm{ml}$-hrs)

$\mathrm{C}_{\max }$ - peak concentration; $\mathrm{T}_{\max }$ - time to attain

$\mathrm{C}$-max; AUC-area under the plasma

concentration vs. time curve; $\mathrm{Cl}$ - clearance

\section{Acknowledgements}

The authors acknowledge Ms. A. Komathi for blood collections and the Department of Clinical Biochemistry and HIVIAIDS Division for investigations. WinNonlin software was a kind gift provided during the training to Hemanth Kumar under the ICER programme, at the University of Alabama at Birmingham, USA. The authors thank the Superintendent and staff of the Government Hospital of Thoracic Medicine, Tambaram, Chennai, India for their co-operation.

\section{References}

1. Burman WJ, Jones BE. Treatment of HIVrelated Tuberculosis in the Era of Effective Antiretroviral Therapy. Am J Respir Crit Care Med 2001; 164: 7-12.

2. American Thoracic Society Documents. American Thoracic Society/ Centers of Disease Control and Prevention/Infection Diseases Society of America. Treatment of tuberculosis. Am J Respir Crit Care Med 2003; 167: 603-662.

3. Acocella G. Clinical pharmacokinetics of rifampicin. Clin Pharmacokinet 1979; 3: 108-127.

4. DuPont Pharmaceuticals Company. Sustiva $^{T M}$ (efavirenz capsules), Prescribing information: 1998 Sep 17: http:// www.sustiva.com. Accessed on 24 April 2007.

5. Montaner JSG, Lange JMA. Nevirapine. AIDS Therapy Chapter 7; 87-96.

6. Lopez-Cortes LF, Ruiz-Valderas R, Viciana $P$, et al. Pharmacokinetic interactions between efavirenz and rifampicin in HIVinfected patients with tuberculosis. Clin Pharmacokinet 2002; 41: 681-690.

7. Ribera E, Pou L, Lopez RM, et al. Pharmacokinetic interaction between nevirapine and rifampicin in HIV-infected patients with tuberculosis. J Acquir Immun Dis Syndr 2001; 28:450-453.

8. Robinson $P$, Lamson $M$, Gigliotti $M$, et al. Pharmacokinetic interaction between nevirapine and rifampicin (abstract 60623). 
In Program abstracts of the XII World Conference on AIDS, Geneva, Switzerland, June 28 - July 3, 1998.

9. Hemanth Kumar AK, Chandra I, Geetha R, Silambu Chelvi K, Lalitha V, Prema G. A validated high-performance liquid chromatography method for the determination of rifampicin and desacetyl rifampicin in plasma and urine. Ind $\mathrm{J}$ Pharmacol 2004; 36(4): 231-233.

10. Gurumurthy $P$, Ramachandran $G$, Hemanth Kumar AK, et al. Decreased bioavailability of rifampin and other antituberculosis drugs in patients with advanced human immunodeficiency virus disease. Antimicrob Agents Chemother 2004; 48: 4473-4475. 